\title{
PRACTICAL OBSTACLES IN CROSS-BORDER LITIGATION AND COMMUNICATION BETWEEN (EU) COURTS
}

\author{
Astrid Stadler*
}

\begin{abstract}
In cross-border civil litigation the use of different official court languages causes severe problems when - at least one of the parties - is not familiar with the official language of the court, since the parties' constitutional right to a fair trial depends very much on the communication with the court. As a consequence, interpreters must often be used during trials and hearings and legislatures have to decide to what extent legal documents should be translated. The article takes the position that the European legislature sometimes underestimates the language problem and does not always provide sufficient safeguards for the parties' right to be heard (in a language they can understand). In particular, the defendant's procedural rights often require a translation of documents in cross-border service of process and must take precedence over procedural economy. European regulations also tend to emphasise the cooperation between courts in different Member States without taking into consideration that there is often no common language and that many judges will not have the language skills to communicate with their colleagues. The use of standard forms available in the 23 official languages is no perfect solution for all situations.
\end{abstract}

Keywords: Fair trial; service of documents; translation of documents; cross-border enforcement of judgments given in default of appearance; judicial cooperation; use of standard forms

\section{Introduction}

The biblical myth about the Tower of Babel ${ }^{1}$ teaches us that multilingualism is a punishment from God. Angry about the arrogance and presumptuousness of the people of Shinar, who spoke a single language and attempted to build a tower "with its top in the heavens', God confused their languages. ${ }^{2}$ After that the earth no longer spoke one language. Despite humankind's often described dream of regaining a common language, ${ }^{3}$ we classify language today as one of the main features of cultural identity. ${ }^{4}$ Law and language are particularly difficult partners. Law depends on language as a medium. Legal systems - whether based on codification or case law - are linguistically fixed, standardised rules that must be understood by the addressees. ${ }^{5}$ Legal regulations, pleadings or court hearings are often incomprehensible to non-lawyers, whether native

\footnotetext{
Professor of Law, University of Konstanz, Germany; Chair of Comparative Mass Litigation, Erasmus University, Rotterdam.

Cf. the canvas by Pieter Brueghel the Elder (The Tower of Babel, 1563). The so-called Rotterdam version is on display at the Museum Boijmans van Beuningen in Rotterdam.

The story is found in Genesis 11:1-9 (King James Version) as follows: '.. Therefore is the name of it called Babel; because the Lord did there confound the language of all the earth, and from thence did the Lord scatter them abroad upon the face of all the earth.'

3 An excellent example is Umberto Eco's La ricerca della lingua perfecta (1993), in which he comes to the conclusion that the multiplicity of languages and the chance to interpret the world differently are lifeenhancing.

${ }_{4}$ For the interdependence of language and identity cf. H. Goebel, P. Melde and Z. Starý, Kontaktlinguistik, Ch. 10 'Identität', at 218 et seq.; H. Haarmann, Basic Aspects of Language in Human Relations (1994); E. Jayme, Sprache und kulturelle Identität im Recht, in G. Reichelt (ed.), Sprache und Recht (2006) 15. S. Fischer, A History of Language (2000), at 211 predicts that owing to the increasing use of communication technology, only English, Mandarin and Spanish will survive the next 300 years.

The comprehensibility of legal texts has been a controversial topic since the Age of Enlightenment. For a general review of Germany cf. the contributions in K. Eichhoff-Cyrus and G. Antos, Verständlichkeit als Bürgerrecht (2008). The 15 ${ }^{\text {th }}$ International Congress of Comparative Law (Bristol 1998) dealt with problems of law and language under the heading of 'Legal Theory'; the national reports are published by E. Jayme, Langue et droit (2000).
} 
speakers or not. This paper, however, will not address the problems involved in the use of a technical language compared with 'normal' language, ${ }^{6}$ but will focus on the multilingualism of the European Union and the practical consequences for cross-border litigation. Comprehension of legal terminology is a general problem that is not specific to cross-border litigation, but one has to own that it makes the situation worse for foreign parties. Even good linguistic skills in general will not guarantee the understanding of legal texts and interaction before the courts.

Much has been said and written about the linguistic diversity ${ }^{7}$ and the consequences of the EU's 23 official languages, ${ }^{8}$ the cost of translation and the problems of divergent terminology in EU documents and legislation. ${ }^{9} \mathrm{EU}$ law has not only guaranteed to respect the diversity of national languages, ${ }^{10}$ but it also provides for the right of every citizen of the Union to address any of the institutions or bodies of the EU in one of its official languages and to receive an answer in the same language (Article 24 [4] TFEU; Article 41 [4] Charter of Fundamental Rights - EUCFR). Despite the armies of interpreters translating documents, deliberations and official meetings, almost all EU institutions only remain functional thanks to an unofficial 'working language' - something that is a politically sensitive issue. ${ }^{11}$ Thus, from the outset there has been no want of proposals demanding a common language ${ }^{12}$ or at least a common 'legal language' to facilitate the coherent use of legal terminology. ${ }^{13}$ The diversity of national languages among Members of Parliament and the Commission has even triggered the idea that each of them must use an official language of the EU that is not his or her mother tongue in order to prevent native speakers from enjoying unfair advantages. ${ }^{14}$ Despite its many problems, multilingualism is one of the cultural treasures of Europe, and the protection of the diversity of languages, particularly the protection of languages spoken by a small number of people, is important for the acceptance of the 'European idea' ${ }^{15}$ Therefore, the high costs involved in translations and in the education of interpreters are worth every Euro. ${ }^{16}$ This paper, however, is based on the thesis that although primary EU law provides a high level of protection against discrimination on grounds of language, this is

\footnotetext{
Since the 1970s, sociologists have remarked that the communicative structure of court proceedings can be a barrier to access to justice. Cf. H. Soeffner, Ursachen von Kommunikationsstörungen vor Gericht, in Wassermann R. and Peterson J. (eds.), Recht und Sprache (1985) 73. ; J. Goebel, Zivilprozessrechtsdogmatik und Verfahrenssoziologie (1994).

For example, X. Aroz (ed.), Respecting Diversity in the European Union (2008); D. Castiglione and C. Longman (eds.), The Language Question in Europe and Diverse Societies (2007).

8 Art. 55 (1) of the Treaty on European Union; Regulation 1, 15 April 1958, OJ 17/1958.

9 For example, D. Martiny, 'Babylon in Brüssel? Das Recht und die europäische Sprachenvielfalt', Zeitschrift für Europäisches Privatrecht 227 (1998); V. Heutger, 'Law and Language in the European Union', 3 Global Jurist Topics Art. 3, 1 (2003); C. Luttermann and K. Luttermann, 'Ein Sprachenrecht für die Europäische Union', Juristenzeitung 1002 (2004).

10 Preamble of the EUCFR: ' $\ldots$ respecting the diversity of the cultures and traditions of the peoples of Europe as well as the national identities of the Member States.' Art. 22 EUCFR: 'The Union shall respect cultural, religious and linguistic diversity.'

11 Luttermann and Luttermann, aboven. 9, at 1003; cf. T. Oppermann, 'Reform der EU-Sprachenregelung?', Neue Juristische Wochenschrift 2663 (2001).

12 Favourites are a three-language model (English-French-German) or a five-language model which adds Spanish and Italian; cf. Luttermann and Luttermann, above n. 9, at 1008; F. Sturm, The European Legal Forum (2002), at 318 favours Latin as lingua franca. For a humorous suggestion of Gaelic - the mother tongue of fewer than $1 \%$ of EU citizens - cf. T. Rauscher, 'Von prosaischen Synonymen und anderen Schäden', Praxis des Internationalen Privat- und Verfahrensrechts 40, at 40-41 (2012).

${ }_{13}$ Heutger, above n. 9, at 11; N. Urban, 'One Legal Language and the Maintenance of Cultural and Linguistic Diversity', 8 European Review of Private Law 51 (2000), emphasises that linguistic diversity cannot be maintained; for a critical review of English as lingua franca, see C. Longman, 'English as Lingua Franca: A Challenge to the Doctrine of Multilinguism', in Castiglione and Longman, above n. 7, 185, at 207. For the European Patent Office in Munich and the European Trademark Office in Alicante the number of official languages has already been reduced to two from five languages.

14 G. Reichelt, 'Sprachliche Gleichberechtigung und ihre Grenzen in der Europäischen Union', in Reichelt, above n. 4, 8.

15 P. Kraus, 'Intercultural Recognition and Linguistic Diversity in Europe', in Castiglione and Longman, above n. 7,76 .

16 The European Commission's Translation Service (DG Translation) presently has a staff of about 2,500 people and is one of the world's largest services of that kind.
} 
in some contrast to the situation of EU citizens involved in cross-border civil litigation. ${ }^{17}$ The paper will thus have a focus on the situation in the EU, but to understand the European development it will be helpful to have a broader picture with respect to some issues.

\section{Different Aspects of the Language Problem in Cross-Border Litigation}

Diversity of languages is a multifaceted problem with respect to court proceedings. For proceedings before the European Court of Justice (ECJ) the choice of official language depends on the plaintiff or - in proceedings for a preliminary ruling - on the court referring the case. ${ }^{18}$ The plaintiff's right to opt for the official language opens the door to 'language shopping' as the selection of a particular language always implies a particular legal culture, legal traditions and terminology. ${ }^{19}$ For civil proceedings before the national courts the situation is different and raises the question of whether there is something like a 'right to language ${ }^{20}$ for the parties. As a principle, cross-border proceedings accept that one of the parties has to litigate in a foreign language. Our existing rules on international jurisdiction also allow to some extent forum shopping by the plaintiff. Thus, he or she also has the option of 'language shopping' as courts regularly have only one official court language, that of the state in which the court is located. ${ }^{21}$ The idea of using a language in court proceedings that is not the official language of the respective state but one which all participants can agree upon (e.g. the English language) is gaining ground only slowly in some Member States and entails new problems. ${ }^{22}$ Consequently, we have to accept that it is not possible to treat parties, natives and foreigners as completely equal. Given that in international cases one party must litigate in a foreign language, it is however extremely important that this does not interfere with that party's basic procedural rights such as the right to be heard or the right to due process.

In civil litigation, it is very often the defendant who has to accept a foreign forum and the use of a foreign language. One of the most important procedural rights of defendants is the right to proper notification at the beginning of the litigation. Not only must they receive the information that an action has been filed against them, but for preparing their defense it is of course also of vital importance also to know the allegations and the legal reasoning of the plaintiff. Thus, language problems appear at the very start of the litigation, when service of process takes place and pleadings preparing the trial are exchanged. With a few exceptions, it is a fundamental procedural principle all over Europe that court decisions, both in civil and in criminal proceedings, are primarily based on oral hearings and trials. Mutual understanding between the court and the parties is therefore indispensable for their interaction. Legal provisions very often provide the right to call in an interpreter during court hearings. ${ }^{23}$ Interpreters, however, are more often used in criminal proceedings in order to guarantee the accused's right to a fair trial. Article 6(3)(e) of the European Convention for the Protection of Human Rights and Fundamental Freedoms [hereinafter: ECHR] provides that anyone charged with a criminal offence has the right 'to have the free assistance of an interpreter if he cannot understand or speak the language used in court'. In civil proceedings, parties do not necessarily attend hearings in person, and if they do, they often do not use interpreters, in order to avoid additional costs. For both foreign parties and interpreters, the situation

\footnotetext{
For a detailed survey of the EU's disparate approach to linguistic matters cf. N. Nic Shuibhne, '(Minority) Languages, Law and Politics: Tracing the EU Action', in Castiglione and Longman, above n. 7, 123.

Rules of Procedure for the Court of Justice of the European Communities (June 1995), Title I, Ch. 6, Arts. 29-31; for details cf. P. Berteloot, 'Multilinguismus am Europäischen Gerichtshof', in Reichelt, above n. $4,27$.

19 Reichelt, above n. 14, at 6.

20 Reichelt, above n. 14, at 2.

21 For the bi- and multilingual context cf. Kruger, Kruger and Bambust in this volume at 211.

22 Cf. contribution by C. Kern in this volume at 187.

23 Below n. 71
} 
in the courtroom is a great challenge. Court documents or pleadings preparing trials written in a foreign language are easier to cope with as translation is less difficult for interpreters if they have more time to do their job well. In any case, the question arises as to who should bear the risk, cost and burden of obtaining a translation. The paper therefore distinguishes between the pleading stage of the litigation and oral hearings, but the situation during trials and hearings will be touched upon more briefly as parties in civil proceedings do not necessarily appear in court, but will often be represented by lawyers with adequate language skills. ${ }^{24}$ The paper will furthermore emphasise that the situation during the litigation is different depending on whether the defendant is a consumer or any other private citizen, an SME, or a big company acting globally in international commerce.

\section{Documents Instituting Civil Proceedings - Service of Documents}

\subsection{Traditional Concepts of Service of Documents Instituting the Proceedings}

Proper service of the documents instituting the proceedings is of utmost importance for the defendant's fundamental right to be heard, which derives from the right to a fair hearing guaranteed by Article 6 ECHR and Article 41(2) of EUCFR. ${ }^{25}$ The key question for cross-border proceedings is therefore whether a translation into the defendant's language provided by the plaintiff is mandatory or not. If defendants must look to a translation themselves, they will possibly have to bear considerable costs. As the time for entering an appearance might be a short deadline for the defendant, obtaining a translation before preparing the defence also takes valuable time. In some cases the defendant might not even realise that the documents he received in a foreign language are official court documents requiring his attention and reaction. Failure to respond may result in a judgement by default against him. Thus, at first sight, it seems adequate and just that the documents instituting the proceedings must be in a language that the defendant can understand.

If we look at the issue in Europe and on a global level, it becomes clear that different responses are given by EU law (i.e. Article 8 European Service Regulation [ESR]) ${ }^{26}$ and by the UNIDROIT/ALI Principles of Transnational Civil Procedure (PTCP) (Principle 5.2). It used to be a traditional concept of international civil procedure that it was the plaintiff's responsibility to provide for a translation of the documents to be served upon the defendant. ${ }^{27}$ This compensates to some extent for the fact that it is the plaintiff who - in accordance with existing rules of international jurisdiction - selects the forum and draws the defendant into court proceedings against his or her will. As it might not be clear what language(s) the defendant in fact understands, the requirement of translation is often formalised and documents must be translated into the official language of the state where the service of documents is to be effected, i.e. the place where the defendant is domiciled. This is traditionally also explained as a requirement with respect to the

\footnotetext{
24 The importance of the language problem with respect to service of process is also emphasised by a number of court decisions - national and European, whereas there is almost no case law (outside criminal law) with respect to translations during court hearings.

${ }_{25}$ For a critical review of this article cf. I. Rabinovici, 'The Right to Be Heard in the Charter of Fundamental Rights of the European Union', 18 European Public Law Review 149 (2012).

${ }_{26}$ Council Regulation 1393/2007/EC on the service in the Member States of judicial and extrajudicial documents in civil or commercial matters (replacing Regulation 1348/2000/EC), OJ 2007 L 324, at 79.

${ }_{27}$ Cf. for example the Austrian High Court (Oberster Gerichtshof), 16 June 1998, 4 Ob159/98f, Österreichische Juristenzeitung, Evidenzblatt (EvBl) 1998/193 and F. Matscher, 'Sprache der Auslandszustellung und Artikel 6 EMRK', Praxis des Internationalen Privat- und Verfahrensrechts 274 (1999).
} 
sovereignty of this state, ${ }^{28}$ but it equally protects the addressee as he or she is most likely to understand the language of the place of his or her domicile. ${ }^{29}$

If the service of documents is not correct owing to the lack of a translation into the defendant's language, procedural rules will often not permit the lawsuit to proceed, or if it does, a judgement by default against the defendant will not be enforceable in other European states. This was the situation under the 1968 Brussels Convention on Jurisdiction and Enforcement of Judgments in Civil and Commercial Matters. ${ }^{30}$ Article 27(2) of the Convention provided that a judgement should not be recognised 'where it was given in default of appearance, if the defendant was not duly served with the document that instituted the proceedings in sufficient time to enable him to arrange for his defence'. Until the first ESR came into force in 2001, the question of due service of documents depended in many cases on the Hague Service Convention ${ }^{31}$ in respect of which many Member States of the EU are contracting states. The Convention allows service of process of judicial documents to be effected by letters rogatory, a formal request from the court where proceedings are pending to the state where the addressee resides. Unless the applicant requests a particular method, the Central Authorities regularly require the documents to be served to be written in, or translated into, the official language of the state addressed (Article 5[3] of the Hague Service Convention). This rule still applies today between the contracting states of the Hague Service Convention if the service of documents is beyond the scope of application of the ESR.$^{32}$

\subsection{The Concept of the ESR}

\subsubsection{Right to refuse acceptance}

The ESR does not - as a matter of principle - require the documents to be served upon a foreign defendant to be translated, but offers instead in Article 8 a very troublesome provision. The concept of the ESR is as follows: the documents to be served upon the defendant need not necessarily be written in or translated into the official language of the state where the defendant resides. If, however, they are not in a language the addressee 'can understand', he or she may refuse to accept the documents. ${ }^{33}$ The addressee must be informed about his or her right of refusal either by the receiving agency requested to transmit the document(s) (Article 8[1]) or by post if the service of the document(s) is being effected directly by post according to Article 14 (Article 8[4]). From the outset, there has been a lot of criticism with respect to the Article 8 regulation, and a survey of the 2001 version of the ESR revealed that the information of the addressee about the right to refusal had become a critical issue in terms of the regulation. ${ }^{34}$ Concerns were raised over the fact that Article 8 of the 2001 ESR gave the addressee the chance of refusing to accept the document to be served only at the time of delivery. If the receiving agencies decided to deliver the documents to be served by first-class mail, for example, it often happened that the addressee accepted the letter, but it was not before

\footnotetext{
28 E. Bajons, 'Internationale Zustellung und Recht auf Verteidigung', in R. Geimer, Wege zur Globalisierung des Rechts (1999) 49, at 71; Opinion of Advocate General Trstenjak, Case C-14/07, 27 November 2007, no. 46 (footnote 5).

29 Historically this presumption was true. With an increasing number of immigrants living in some countries without having respective language skills, this argument loses some weight.

30 OJ C 27, 26 January 1998, at 1-27.

31 Convention of 15 November 1965 on the Service Abroad of Judicial and Extrajudicial Documents in Civil or Commercial Matters.

32 This applies to all Member States of the EU, including Denmark.

33 Cf. B. Sujecki, 'Übersetzungserfordernis nach Zustellungsverordnung', Zeitschrift für Europäisches Privatrecht 359 (2007), for further reference.

34 The Commission's report on the application of Regulation 1348/2000, published in 2004 based on a study, admitted that 'the application of Article 8 is not entirely satisfactory, in particular as the addressee is not always informed of his right to refuse to accept the document (see Annex IV) ...', Report SEC (2004) 1145, COM (2004) 603 final, at 4; for a critical review cf. also H. Linke, 'Europäisches Zustellungsrecht', ERA Forum 205 (2005).
} 
the letter was opened that he or she realised that the documents were written in a foreign language that he or she did not understand. Then, however, it was already too late to refuse acceptance.

This practical problem was tackled by the 2007 version of the new ESR, which now provides in Article 8 that the addressee may refuse to accept the document either at the time of service or by returning the document to the receiving agency within one week. Another very important improvement made by the new ESR is that the standard form provided in Annex II of the Regulation must be used to inform the addressee about the right to refuse acceptance. The standard form is available in all 23 official languages and indicates the rights of the addressee. ${ }^{35}$

Furthermore, the 2007 ESR reform clarified to some extent the legal consequences of the defendant's refusal. In 2005, the Dutch Hoge Raad had referred the Leffler case to the ECJ, pointing out that Article 8 ESR did not prescribe the consequences of a refusal to accept service. ${ }^{36}$ Berlin Chemie, a German company, had refused to accept documents instituting proceedings in the Netherlands on the ground that the documents had not been translated into German. One could either assume that, once the addressee has for good reasons refused to accept the document, no service of the documents has in fact taken place, or that it should be permissible to rectify the defect of service by subsequently providing the addressee with a translation. ${ }^{37}$ The Court favoured an autonomous interpretation and derived from the regulation's aim to ensure that documents are transmitted rapidly and efficiently so that it is possible for the sender to remedy the lack of translation, after the addressee's refusal to accept the documents, by sending a translation. ${ }^{38}$ The translation must be delivered to the addressee in accordance with the procedure laid down in the ESR as soon as possible.

Article 8(3) of the 2007 ESR has implemented this rather practical approach of the ECJ. Nevertheless, it increases the risk that plaintiffs will, first of all, try to effect service of documents without any translation and wait to see whether the defendant refuses to accept it. ${ }^{39}$ In any case, it is very clear that the responsibility with respect to the preservation of the defendant's right to be heard has been placed on the defendant now. He or she must be aware of the consequences of accepting documents without translation and must object within a brief period of one week. Big companies with a legal section equipped to handle these cases will have no problems in preserving their rights. Ordinary people or SMEs with less or no experience of cross-border litigation might feel irritated if translations are incomplete or entirely missing and might not realise that they will impair their procedural situation unless they react promptly. Therefore, this shift cannot be accepted.

\subsubsection{Level and proof of language skills}

Even though the 2007 reform of the ESR eliminated some of the most urgent practical problems and deficiencies of the original version, it maintained 'the root of all evil', i.e. the ambiguous wording of Article 8(1). The addressee may refuse to accept the

\footnotetext{
35 On the importance of reliable information supplied by a standard form cf. A. Stadler, 'Sprachprobleme im Europäischen Zivilprozessrecht', in P. van der Grinten, P. Meijknecht and F. van der Velden (eds.), Practical Obstacles in Cross Border Litigation 11 (2005).

36 ECJ C-443/03, Leffler v. Berlin Chemie, [2005] ECR I-9611.

For the plaintiff, the difference between the two options is important. Assuming that non-compliance with Art. 8 ESR results in the nullity of the document, the plaintiff could be placed in a difficult position if the documents have to be served within a particular period (e.g. with respect to statutes of limitation).

38 ECJ C-443/03, Leffler v. Berlin Chemie, [2005] ECR I-9611, no. 43 et seq.

A. Stadler, 'Ordnungsgemäße Zustellung im Wege der remise au parquet und Heilung von Zustellungsfehlern nach der EuZustVO', Praxis des Internationalen Zivil- und Verfahrensrechts 116, at 123 (2006). The Commission's Report on the application of Regulation 1348/2000 in 2004 revealed that the possibility to serve documents in a language other than the official language of the Member State addressed was used in 54\% of cases; Report COM (2004)603 final, Ann. III. Some commentators have suggested that in case of misuse by the plaintiff - who is aware that the defendant does not understand the language in which the documents are written and nevertheless refrains from delivering a translation for a start - she or he should not benefit from the 'double date' regulation in Art. 8(3), Sujecki, above n. 33, at 365.
} 
documents only if they are not written in, or translated into, a language he or she "can understand' ${ }^{40}$ This vague description of a standard of language skills does not provide a solid basis for the defendant's right to be heard. ${ }^{41}$ Who is going to decide on the defendant's language skills, and how? Many questions raised are still unsolved today - more than 10 years after the regulation came into force. What standard or level of language is required? Will 'normal' language skills suffice or must the addressee be able to understand legal terminology? If the addressee is not a person but a legal entity, who is to 'understand' the documents served upon the entity? Should it be the legal representative of the legal entity, one of the board members or one of the employees? Or can courts simply assume that the legal entity 'understands' the official language of the state where it is domiciled or registered?

'The question whether or not a person understands a foreign language ultimately depends on his own judgment. ${ }^{42}$ This statement by Advocate General Trstenjak will be widely accepted. Nevertheless, it is also plausible that the effectiveness of service cannot depend entirely on the will of the addressee. ${ }^{43}$ It is not only extremely difficult to prove that the defendant definitely has certain language skills, but plaintiffs and courts are also often not able to test these skills before the service of documents instituting the proceedings takes place. Thus, objective criteria are required that might indicate or even give a presumption of certain language skills. Consequently, it has to be taken into account that the interpretation of Article 8 ESR must not only do justice to the defendant's right to be heard, but also prevent any abuse of the right to refuse acceptance should the defendant purely seek to delay matters. In the Ingenieurbüro Weiss case, the ECJ tried to balance the interests of both parties. In a case pending before German courts, IHK Berlin was pursuing an action for damages against the British architecture firm Grimshaw for breach of contract. In the contract, Grimshaw had stipulated that the services should be provided in German and correspondence between the contracting parties and authorities and public institutions should be in German. The contract was governed by German law and included a forum selection clause in favour of German courts. Nevertheless, Grimshaw initially refused to accept service of court documents on the ground that there was no English translation and that none of the organs representing Grimshaw spoke German. Therefore, one of the questions referred by the German Federal Civil Court (Bundesgerichtshof) to the ECJ was whether the contract clause allowed the conclusion that the defendant understood German within the meaning of Article 8 ESR. Advocate General Trstenjak had taken the position that Grimshaw had indeed indicated that it had sufficient linguistic knowledge with respect to correspondence with authorities and public institutions. Therefore, it could be assumed that a rebuttable presumption was justified based on the impression created by the defendant that it understood German. ${ }^{44}$ The ECJ did not go as far as that and rejected the position that a language clause in a contract between the parties gives rise to a presumption of knowledge of the agreed language. Instead, courts must examine all the relevant evidence submitted by an applicant in

40 The 2001 version of Art. 8 ESR provided the addressee with a right of refusal if the documents were - inter alia - not translated into 'the language of the Member State of transmission which the addressee understands'. The 2007 review abolished the requirement that translation must be in the language of the Member State of transmission. Now, the addressee is not entitled to refuse acceptance if the documents are translated into any language he or she can understand. With this change in the wording of Art. 8, the European legislature was intended to promote the use of English in cases where English is not the official language in the state where the litigation is pending but the parties have, for example, already negotiated their contract in English, and contract documents are written in English.

41 A. Stadler, 'Neues Europäisches Zustellungsrecht', Praxis des Internationalen Zivil- und Verfahrensrechts 514, at 517 (2001); W. Lindacher, 'Europäisches Zustellungsrecht', 114 Zeitschrift für Zivilprozess 179, at 183 et seq (2001).

42 Opinion of Advocate General Trstenjak, above n. 28, at no. 74.

43 ECJ C-14/07, Ingenieurbüro Weiss, [2008] ECR I-03367, no. 84.

44 Opinion of Advocate General Trstenjak, above n. 28, no. 79-81; also B. Sujecki, 'Das Annahmeverweigerungsrecht im Europäischen Zustellungsrecht', Europäische Zeitschrift für Wirtschafsrecht 363, at 366 (2007); A. Stadler, 11 Zeitschrift für Zivilprozessrecht International 227, at 235 (2006). The defendants and also the Czech and Slovak governments had argued, however, that the degree of knowledge of a language required for correspondence was not the same as that needed to defend an action before the court; cf. ECJ C-14/07, Ingenieurbüro Weiss, [2008] ECR I-03367, no. 83. 
order to establish whether the addressee of the documents understands the language in which the judicial documents are written. ${ }^{45}$ Ultimately, the difference between the two positions of the Advocate General and the ECJ lies in the burden of proof. A rebuttable presumption helps the plaintiff to prove that the requirements of Article 8 are met, but offers the defendant the chance to rebut the presumption in accordance with the rules on evidence of the Member States in which the proceedings are pending. According to the ECJ the burden of proof lies entirely with the plaintiff, if there is doubt about language skills. ${ }^{46}$

The ECJ rightfully imposes on trial courts the obligation to examine the requirements of Article 8 ESR carefully. The decision also allows the conclusion that rudimentary linguistic knowledge is not sufficient for the purpose of Article 8 ESR. The addressee's proficiency in a language must be good enough for him/her essentially to understand legal documents ${ }^{47}$ However, according to the ECJ contract clauses on the language to be used in correspondence with public authorities, choice-of-forum and choice-of law clauses may provide some evidence as to the knowledge of legal terminology. In this respect, one should bear in mind that a contracting party might have agreed to a particular language in a contract although he or she had no sufficient linguistic knowledge of the language and intended to obtain translations (in-house or from outside). For the performance of a contract this is doubtless acceptable, but it is highly questionable whether such a courtesy extended to the contractual partner can put a party in a worse position with respect to court documents. Thus, parties should be very reluctant to accept such clauses and courts should apply stricter standards to protect cross-border consumers who have contractually agreed that correspondence is to be conducted in the language of the undertaking. ${ }^{48}$ The ECJ's decision - which was welcomed by academics to a broad extent ${ }^{49}$ - does not list any further criteria for determining language skills and does not even indicate whether courts should refer to the linguistic knowledge of legal representatives - obviously the position taken by the Bundesgerichtshof $f^{50}$ - or whether reference to the registered office of the legal person is the relevant connecting factor in terms of the linguistic knowledge of a legal person. ${ }^{51}$

\subsubsection{The importance of reliable standards}

The importance of fixed and reliable language standards is apparent when we address the question of who decides on the language skills of the defendant. First of all, it is up to the court where the action is pending and the plaintiff to decide whether the documents instituting the proceedings are to be translated or not. If the defendant refuses to accept the documents without translation and the plaintiff denies providing a translation, the court will have to decide whether the addressee rightly refused acceptance. If the court takes the position that he or she had sufficient language skills and was not entitled to refuse acceptance, proceedings will go on. This is particularly dangerous for a defendant who has sent back the documents, refusing to accept service of process (Article 8[1]). If he or she has not retained a copy of the documents, he or she is left without any

45 ECJ C-14/07, Ingenieurbüro Weiss, [2008] ECR I-03367, no. 85-88.

46 Cf. P. Bohunova, 'Regulation on Service of Documents: Translation of Documents Instituting Proceedings Served Abroad', sub 4, available at: http://www.muni.cz/research/publications/818211.

47 ECJ C-14/07, Ingenieurbüro Weiss, [2008] ECR I-03367, no. 83, 87.

48 This was also the position of the referring Bundesgerichtshof in the Ingenieurbüro Weiss case, ECJ C-14/07, Ingenieurbüro Weiss, [2008] ECR I-03367, no. 37.

49 Sujecki, above n. 44, at 365-366; M. Ahrens, 'Neues zum Annahmeverweigerungsrecht im europäischen Zustellungsrecht', 39 Neue Juristische Wochenschrift 819 (2008); B. Hess, 'Übersetzungserfordernisse im europäischen Zivilverfahrensrecht', Praxis des Internationalen Zivil- und Verfahrensrechts 400, at 403 (2008); Bohunova, above n. 46.

50 Bundesgerichtshof, 11 Zeitschrift für Zivilprozess International 220, at 224 (2006); R. Schütze, 'Übersetzungen im europäischen und internationalen Zivilprozessrecht - Probleme der Zustellung', Recht der Internationalen Wirtschaft 352, at 353 (2006).

51 This was mentioned as 'the only practicable solution' by Opinion of Advocate General Trstenjak, above n. 28, at no. 72; a similar position is taken by Bajons, above n. 28, at 73; Stadler, above n. 41, at 518; Sujecki, above n. 33, at 359; Lindacher, above n. 41, at 187. 
information on the subject matter of the case! If a judgement based on the defendant's failure to appear in court is issued, ${ }^{52}$ the defendant may raise the objection of Article 34(2) of the Brussels I Regulation in the state of enforcement. Courts there might take the position that the defendant was not able to understand the documents and that service was therefore not 'in sufficient time and in such a way as to enable him to arrange for his defence' (Article 34[2] Brussels I Regulation). Then, the plaintiff is caught between the devil and the deep blue sea. Enforcement of the judgement is not possible in the state where the defendant is living. The deficiencies with respect to the service of documents identified by the courts in the state of enforcement will probably only be cured by new litigation. In the state of origin, however, new litigation will regularly be barred by the res judicata effect of the first judgement. Proceedings in another Member State, including the defendant's domicile, might be impossible owing to the exclusive jurisdiction of the courts in the Member State where the first proceedings were instituted.

Since the 2007 reform of the ESR, Article 8(3) offers the plaintiff the chance to avoid this catch-22 situation. If the defendant refuses to accept the documents to be served upon him/her owing to the lack of a translation, the plaintiff should not wait to see whether courts consider the refusal to be justified or not but deliver a translation in order to play it safe. The ECJ decision in the Leffler case and Article 8(3) (which refers to [1]) ESR apply only to a rightful refusal to accept service of documents. Nevertheless, owing to the unpredictability of the interpretation of Article 8 para. 1 ESR, plaintiffs would be well advised to provide a translation in any case. ${ }^{53}$

From the perspective of the defendant, the situation has become more difficult as the EU Commission became committed to paving the way for the abolition of exequatur proceedings. As a first step, in 2004 the European Enforcement Order Regulation abolished exequatur proceedings for judgements on an uncontested claim certified as a European Enforcement Order. Claims are - inter alia - to be regarded as 'uncontested' if the debtor has not objected to it in the course of the court proceedings or has not appeared at a court hearing. ${ }^{54}$ Therefore, if the defendant does not react promptly and does not refuse to accept the documents instituting the proceedings based on Article 8 ESR, there is no longer the chance to object to an enforcement of a judgement by default. Without exequatur proceedings the objection of Article 34(2) Brussels I Regulation cannot be evoked. The same applies to judgements given under the European Small Claims Procedure Regulation ${ }^{55}$ or the European Regulation relating to maintenance obligations,${ }^{56}$ both of which also abolished exequatur proceedings ${ }^{57}$ In a recast of the Brussels I Regulation, the European Commission recently proposed to abolish exequatur proceedings. ${ }^{58}$ In the case of a judgement by default the defendant will - according to the Commission's proposal - have a remedy only in the state of origin of the judgement. ${ }^{59}$

\subsubsection{Conclusion}

EU regulations on the service of documents together with the step-by-step abolition of exequatur proceedings have gradually shifted the 'language risk' to defendants and,

\footnotetext{
52 Some provisions attempt to guarantee that judgements by default are not issued immediately or that the defendant has a remedy against such judgements: cf. Art. 19 ESR; Art. 18 European Enforcement Order Regulation; Art. 15 Hague Service Convention.

53 Plaintiffs might, if necessary, plead that the defendant should not benefit from the Art. 8 para. 3 regulation ('double date'): cf. Sujecki, above n. 33, at 365; H. Rösler and V. Siepmann, 'Zum Sprachenproblem im Europäischen Zustellungsrecht', Neue Juristische Wochenschrift 475, at 477 (2006).

54 Art. 3 (1) (b), (c) Enforcement Order Regulation.

55 Regulation (EC) 861/2007 of 11 July 2007 establishing a European small claims procedure.

56 Regulation (EC) 4/2009 of 18 December 2008 on jurisdiction, applicable law, recognition and enforcement of decisions and cooperation of matters relating to maintenance obligations, OJ 2009 L 7, at 1 et seq.

57 Art. 20 European Regulation on Small Claims Procedure; Art. 17 European Regulation on Maintenance Obligations for decisions given in a Member State bound by the 2007 Hague Protocol.

58 COM (2010), 748 final.

59 Art. 45. Then it is at least not unlikely that the courts with jurisdiction for that remedy will take the same position as the trial court in the same state with respect to the language requirements of Art. 8 ESR.
} 
consequently, have curtailed their right to be heard. The original concept of the ESR was not acceptable owing to the risk it implied that defendants might not realise the importance of court documents written in a foreign language and thus unknowingly could miss the opportunity to defend the case. Since 2007, defendants must pay strict attention to instructions given in standard forms, ${ }^{60}$ and it has become extremely important that they react promptly if they do not understand the document's language. ${ }^{61}$ In particular, with respect to private citizens and SMEs without experience in crossborder litigation, EU regulations should not reduce the chance of contesting proper service of the complaint in the state of enforcement. Advocate General Trstenjak has already pointed out in the Ingenieurbüro Weiss case that the protection of defendants and their right to a fair hearing must take precedence over procedural economy. The choice of a simplified international form of service such as the ESR must not affect the legal guarantees to be afforded to the defendant. ${ }^{62}$ Although it was necessary to make the cross-border service of documents in Europe faster and more efficient, this should not entirely be at the cost of the defendant's rights. Direct service by post has already made transmission of documents much faster.

\subsection{Requirements for Service of Documents outside Europe}

In the light of the traditional concept of cross-border service of judicial documents, it is somewhat surprising that the ECJ emphasises as a matter of course that 'neither the Community legislature nor the Member States consider it to be a necessary component of the exercise of the defendant's right to defence that the applicant provide a translation of the document instituting the proceedings, since the defendant must simply be given sufficient time to enable him to have that documents translated and to prepare his defence' ${ }^{63}$ One might conclude from such a statement that even the right to refusal still enshrined in Article 8 ESR cannot be taken for granted for the future. It is, however, an imbalance of the parties' interests if the defendants have to bear the risk, costs and delay of translation. The right to be heard is a guarantee provided by national constitutions, EUCFR, and the ECHR which addresses legislatures and courts. They have the responsibility for not violating the defendant's right, and it certainly does not suffice merely to give him the opportunity to take care of it by himself.

With respect to proceedings relating to states outside the European 'area of freedom, security and justice', things look a little different. Even though the 1965 Hague Service Convention does not explicitly lay down a general obligation to translate all the documents to be served, it is general practice to require a translation (notwithstanding the addressee's right to accept documents without translation voluntarily). ${ }^{64}$ If the service of process of documents instituting the proceedings was not proper, most states offer the chance to object to the enforcement of a foreign judgement by default against the defendant. Requirements to be met for the recognition of foreign judgements issued outside the EU are defined by the national law of the Member States, but the standard is often the same as set out formerly by Article 27(2) of the Brussels Convention. ${ }^{65}$

\footnotetext{
60 The standard form Ann. II of the ESR requires that an addressee who refuses to accept the documents must indicate what languages he or she understands. This is intended to tie the addressee to a language option although he or she is probably not aware that ticking a box might have a binding effect on the next attempt at service. Addressees should therefore be very reluctant to indicate language skills, unless they are sure that they understand legal terminology or they are willing to accept the risk of obtaining a translation themselves and at their own cost.

61 In the Ingenieurbüro Weiss case, the ECJ also held that it was not necessary to translate all annexes to the complaint served upon the defendant. 'Documents to be served' are those necessary to identify with a degree of certainty the subject matter of the claim and the cause of action. Documents that have a purely evidential function and are not necessary for the purpose of understanding the subject matter of the action form no integral part of the documents 'instituting the proceedings'. ECJ C-14/07, Ingenieurbüro Weiss, [2008] ECR I-03367, no. 73.

62 Opinion of Advocate General Trstenjak, above n. 28, at no. 47.

63 ECJ C-14/07, Ingenieurbüro Weiss, [2008] ECR I-03367, no. 56.

64 Art. 5(2) Hague Service Convention.

${ }^{65}$ Cf. for example the almost identical provision in Sec. 328 no. 2 of the German Code of Civil Procedure.
} 
The PTCP, adopted by UNIDROIT and the American Law Institute in 2004, provide standards for the adjudication of transnational commercial disputes. They may according to the drafters - be equally appropriate for the resolution of most other kinds of civil disputes and, furthermore, they may be the basis for national initiatives in reforming civil procedure. ${ }^{66}$ The PTCP take a very clear and traditional position with respect to the language problem and overcome the temptation to sacrifice the defendant's rights for the sake of fast and cost-efficient service of process. Principle 5.2 PTCP requires translation 'into the language of the state of the individual's habitual residence or a jural entity's principal place of business or into the language of the principal documents of the transaction'. In terms of legal certainty this is definitely more specific, predictable and independent of the defendant's individual language skills. It thus avoids the difficulty of courts having to assess what language the defendant might 'understand'.

As mentioned above, the traditional international concept that documents to be transmitted to another state must be translated into the official language of the state addressed was to some extent based on the mutual acknowledgement of national sovereignty. With respect to its second, no less important, function, to preserve the defendant's right to be heard, the concept should be retained even within a community such as the European Union where national sovereignty is of less importance with respect to international judicial cooperation.

\section{Pleadings and Documents in General}

The complaint or any other documents instituting proceedings are particularly significant in terms of informing the defendant that an action against him or her has been filed. For pleadings submitted by the parties in the course of the proceedings, the rules of the lex fori apply and service upon the other party is not required by European or international rules. ${ }^{67}$ National regulations will - as a rule - provide that pleadings have to be submitted in the official language of the court. This is also the position taken by the PTCP (Principle 5.2, 6). Principle 6.1 PTCP provides that 'the proceedings, including documents and oral communication, ordinarily should be conducted in a language of the court'. It cannot be denied that this is to some extent to the disadvantage of the foreign party who has to provide translations and take care to submit them in due time if a deadline is set by law or by the court. ${ }^{68}$ According to Principle 6.3, however, 'translation of lengthy or voluminous documents may be limited to portions, as agreed by the parties or ordered by the court'. If a party does not submit a translation of his or her, courts will not regularly arrange for translation ex officio, but will, at best, notify the submitting party that a translation is missing.

When the Brussels Convention was replaced by the Brussels I Regulation in 2001, the wording of Art. 27 no. 2 - now Art. 34 no. 2 of the Regulation - changed. It is no longer necessary that service of the documents instituting the proceedings was formally correct as long as it was in the due time. Furthermore, defendants cannot raise an objection if they failed to commence proceedings to challenge the default judgement in the state of origin when it was possible to do so.

${ }^{66}$ Cf. 'Scope and Application', ALI/UNIDROIT Principles of Transnational Civil Procedure, 4 Uniform Law Review 758 (2004).

${ }^{67}$ Even if the plaintiff later submits a pleading extending his/her claims, European regulations do not require service of these documents. Art. 34 no. 2 Brussels I Regulation does not refer to those documents (S. Francq, in U. Magnus and P. Mankowski, Brussels I Regulation (2012), Art. 34 no. 38, 39), and the German Bundesgerichtshof held in 1999 that a US court judgement could be recognised and enforced although the complaint served upon the defendant had not set forth the exact amount of damages. General notice on the factual and legal basis of the claim is sufficient with respect to German public policy, Bundesgerichtshof, Neue Juristsische Wochenschrift (1999), 3198, 3200. The defendant cannot raise the public policy objection if the plaintiff extends his/her claims in a pleading that has been later submitted to the court and has not been served upon the defendant in accordance with international rules. Once the defendant has notice of the litigation, it is up to him/her to participate or obtain information; Bundesgerichtshof, Neue Juristische Wochenschrift (1990), at 2202.

${ }_{68}$ German case law states very clearly, for example, that any request for relief and any motion for appeal or other legal remedy must be filed in German to be legally effective; cf. Bundesgerichtshof, Monatsschrift des Deutschen Rechts 949 (1981); C. Armbrüster, 'Fremdsprachen in Gerichtsverfahren', Neue Juristsische Wochenschrift 812, at 813 (2011). 
With respect to documents submitted to the court as evidence, national rules on evidence also apply. Details cannot be discussed in this paper, but it seems that some national rules are more liberal than pleadings in this respect. German civil procedure rules allow, for example, the use of documents written in a foreign language as evidence and it is up to the court to decide whether translation is required or not (Section 142 German Code of Civil Procedure). This is based on the principle that a court has no obligation to consult experts if the judges have sufficient knowledge themselves. If the court decides it has sufficient language skills to understand documents written in a foreign language, but the opponent has not, it is up to the latter to obtain a translation of the document(s). Translation costs will then become part of the general costs of litigation and are subject to the 'loser pays rule' ${ }^{69}$

\section{Court Hearings and Trial}

It has been pointed out above that the situation in the courtroom is especially challenging for foreign parties. It is a well-established worldwide principle that communication before civil courts is conducted in the official language of the court (or in one of the official languages if there is more than one in a state $\left.{ }^{70}\right) .{ }^{71}$ It is also laid down in the PTCP (see above Principle 6.1). Principle 6.1(2) PTCP allows the use of other languages in all or part of the proceedings if no prejudice to a party will result. In civil proceedings, the use of a foreign language is sometimes less embarrassing for foreign parties than it is in criminal proceedings because parties often do not appear in person before the courts. Big companies will often send only their lawyers or have the option to choose a member of their legal department with the respective language skills - owners or representatives of SMEs, however, may not have that option and often appear in person - at least if large sums are at stake. Consumers enjoy the privilege of litigating before the courts of their own state, but European regulations extend that protection only to consumer contract cases and not to tort cases. ${ }^{72}$ Thus, private citizens who are, for example, injured during a holiday abroad are not entitled to the same protection and must be aware that they will need to litigate before foreign courts. In tort cases, the language problem is particularly evident, as it is often required that the parties attend a court hearing and be available for party deposition or interrogatory to describe what has happened.

If foreign parties do appear in court or are ordered to do so by the court, they regularly have the right to call in an interpreter (thus assuming an additional risk of costs). This has also been accepted as a basic procedural principle by the Principles of Transnational Civil Litigation. Principle 6.3 sets forth: 'Translation should be provided when a party or witness is not competent in the language in which the proceeding is conducted'. It is, however, a matter of common knowledge that even very good interpreters are not able to translate the full meaning of the original. They are experts in a language but not necessarily familiar with details of legal terminology ${ }^{73}$ or with the subject matter of the litigation, which can be rather 'technical' sometimes. Again, undertakings with an

\footnotetext{
69 Armbrüster, above n. 68, at 814 .

70 Cf. for example the situation in Canada or Switzerland (Art. 129 of the new Federal Civil Procedure Code provides that the official language of each Kanton shall be used and leaves it to the Kantone to set out the details in several languages: for details, see D. Richter, Sprachenordnung und Minderheitenschutz im schweizerischen Bundesstaat (2005)). For the situation in Belgium cf. U. Loeckx, 'Das Sprachenrecht der Schweiz und Belgien', Diss. (2003). For a criminal proceeding in Italy (Südtirol), the ECJ held in C-274/96, [1998] ECR I-7637 that German residents must have the same right as Italians residing in Südtirol to use the German language before Italian courts; cf. M. Bulterman, 36 CMLR [1999], 1325-1334.

${ }^{71}$ For example, Secs. 32-36 Estonian Code of Civil Procedure; Art. 23, 23-1 Nouveau Code de Procedure Civil (France); Secs. 184, 185 Judicature Act Germany; Arts. 122-124 Codice de procedura civile (Italy); Arts. 2, 8 Law on the State Language (Lithuania); Arts. 1, 3 Loi du 24 février 1984 sur le régime des langue (Luxembourg); Arts. 142, 143 Ley de Enjuiciamiento Civil (Spain).

72 Cf. Art. 15 Brussels I Regulation; Art. 6(1)(d) European Enforcement Order Regulation; Art. 6(2) European Payment Order Regulation.

${ }_{73}$ For a general discussion of 'technical' or legal terminology as a problem in court proceedings and the challenge to the interpreters involved, cf. G. Ellscheid, 'Sprachprobleme im Gerichtsverfahren', in G. Grewendorf, Rechtskultur als Sprachkultur (1992) 275, at 276 et seq.
} 
international staff will have the advantage of using their own employees as interpreters or can hire a team of lawyers with bilingual skills. As a consequence, interpreters can often not prevent foreign parties having the feeling that they are in a less favourable position than their counterpart who speaks the language of the court.

Nevertheless, it is both legally and psychologically very important to use (good) interpreters. Defendants will be more willing to accept a court decision when they have the feeling that they have had a fair chance to present their arguments to the court and there is no suspicion of 'private negotiations' between the judge and the other party. Even the chance of a settlement of the case will probably be much better if the foreign party - who is present at the hearing or trial - fully understands the position of the court and the proposals for settlement. One important step to cope with the inevitable problems of translation is that courts must at least be aware of these difficulties encountered by a foreign party and must try to avoid discrimination as far as possible. Principle 3.2 PTCP rightly emphasises the important role of the judge: 'The right to equal treatment includes avoidance of any kind of illegitimate discrimination, particularly on the basis of nationality or residence. The court should take into account difficulties that might be encountered by a foreign party in participating in litigation'. Courts preparing hearings or trials should check in advance whether the foreign party will or must attend the session and should clarify whether translation is necessary. Interpreters should be given the chance to study court files to become familiar with the specific terminology of the case whenever it seems suitable. ${ }^{74}$ During hearings and trials, interpreters must be given adequate time to translate and should be encouraged to translate sentence by sentence instead of giving only a short summary of what has been said. ${ }^{75}$ Courts should avoid giving the foreign party the impression that the translation is an embarrassing delay of proceedings.

\section{Communication between Courts, Particularly in the EU}

\subsection{The Hague Conventions' Concept of Letters Rogatory}

So far we have looked at the practical and legal obstacles that foreign parties face in civil litigation resulting from language issues. Within the $\mathrm{EU}$, however, judicial cooperation between courts and judges is becoming more and more important. This is because the traditional and very formal system of mutual assistance between courts by letters rogatory has been abandoned within the EU with respect to the service of documents or the taking of evidence. The Hague Service Conventions and the Hague Convention on the Taking of Evidence were already a step ahead in terms of the efficiency of mutual assistance as they offered the option to address letters rogatory to so-called 'Central Authorities' in the Contracting States. Compared with the traditional use of diplomatic and consular channels, the handling and execution of letters rogatory became faster and easier. Staff members handling requests for judicial assistance in the Central Authorities were often specialists and, above all, had a good knowledge of foreign languages, particularly English. The Hague Conventions tackled the language problem: Article 4 of the Hague Evidence Convention requires a translation of letters rogatory into the language of the Contracting State addressed. Articles 3 and 7 of the Hague Service Convention specify that requests must be communicated on a standard form provided in the Annex to the Convention in English or French. Entries on the standard form can be made in English, French or the language of the Contracting State addressed (Article $7[2])$.

\footnotetext{
74 Ellscheid, above n. 73, at 282.

75 This has been emphasised particularly with respect to the translation of witness statements: cf. Ellscheid, above n. 73 , at 279-281 with further references.
} 


\subsection{Judicial Cooperation within the EU}

When in 2001 and 2004 the Hague Conventions were displaced by the ESR and the European Evidence Regulation (EER), mutual judicial assistance became even less formal. It is no longer necessary to issue formal letters rogatory to a Central Authority, as instead direct communication between the courts ${ }^{76}$ is provided as the regular method for submitting requests. As transmission of requests and documents should be effected directly between the 'transmitting' and the 'receiving' agencies, the use of standard forms has gained importance. They must be completed in the official language of the Member State addressed in order to facilitate speedy handling. It goes without saying that the use of such set forms requires standardised phrases and wording and thus reduces communication and the information given to an absolute minimum. Standard forms can be used, however, without the need for foreign language skills. As they are available in all 23 official languages, courts and agencies can use the form provided in their own language to help them complete the form written in the language of the Member State addressed.

Nevertheless, the use of standard forms is not appropriate and not sufficient in all cases. It works quite well for inter-court communication with the ESR, where the request refers only to the transmission of documents. If we consider the taking of evidence abroad based on the EER, communication becomes more complicated. Article 3 EER allows direct communication between the courts, and requests must be submitted in the language of the Member State addressed or one of the languages that the Member State has indicated it will accept (Article 5[1] EER). The standard form A to be used, however, cannot be completed only by ticking boxes. The requesting court must give information on the nature and subject matter of the case, including a brief statement of the facts. In case of requests for witness testimony, the request must set forth the questions to be put to the witness and provide information on the possible rights of the witness to refuse to testify under the law of the requesting Member State. Thus, it is clear that courts will not be able to issue the request themselves unless judges have the necessary language skills. One can assume that there is probably a broad range of different levels and standards of language skills of judges in the 27 Member States. Some, particularly the younger ones, might have a good command of the English language, but very often it will be necessary to ask for the support of interpreters. As cross-border cases are not the everyday business of judges, it would seem advisable to establish service facilities in large courts or use the existing Central Authorities ${ }^{77}$ to help judges with outgoing requests.

When it comes to the cross-border taking of the evidence, interpreters will often be necessary as well. ${ }^{78}$ According to Articles 11 and 12, EER parties, their representatives and representatives of the requesting court have the right to be present during the taking of evidence and they may ask for their (active) participation (e.g. asking questions of the witness themselves). As the requested court executes the request in general in accordance with the law of its Member States (Article 10[2] EER), the official language of this Member State will be used. The EER - upon request - also allows the direct taking of evidence by the requesting court (Article 17 EER), which is one of the most important improvements compared with the Hague Evidence Convention. It must be performed on a voluntary basis and in accordance with the law of the requesting court (Article 17[3] EER). Therefore, it is possible to use the official language of the requesting court, ${ }^{79}$ which might be a great advantage if all the persons participating ${ }^{80}$ are able to understand and speak that language.

\footnotetext{
76 Following the terminology of Art. 2 ESR, these are the 'transmitting agencies' and the 'receiving agencies'.

77 Art. 3 ESR; Art. 3 EER.

78 For the costs of interpreters cf. Art. 18(2) EER.

79 J. von Hein, in T. Rauscher (ed.), Europäisches Zivilprozessrecht, Kommentar, Vol. 2 (2006), Art. 17 no. 19 with further references; conversely, however, P. Schlosser, EU-Zivilprozessrecht (2009), Art. 17 EER no. 3 (language of the requested Member State).

${ }_{80}$ If the requested Member State, however, designates a court of its own to participate in the taking of evidence (Art. 17[4] EER), it will often impose the condition that the law of the requesting state is used.
} 


\subsection{Interim Result}

As an interim result, one may conclude at first glance that the idea behind the European rules on judicial cooperation of strengthening direct transmission between courts is a convincing concept. Channels of transmission are shorter and more direct. With respect to language problems, however, direct communication raises new difficulties. The use of standard forms necessarily reduces communication to very basic information and may lead to misunderstanding. In many situations, particularly in the cross-border taking of evidence, interpreters are still necessary.

\subsection{Direct Communication without Standard Forms}

More and more it seems to be taken for granted that judges within Europe are able to communicate with each other directly, even on rather complicated matters. The proposed Article 31 of a new Brussels I Regulation is a good example of that approach and will be rather challenging for courts if it comes into force. The article refers to a situation where a court in one Member State is seized with the main proceedings and one of the parties files an application for provisional measures in a court of another Member State (e.g. because the opposing party has assets there to be seized). In order to prevent conflicting provisional court orders with respect to the same dispute, the Commission proposes in Article 31(1) that the courts concerned shall cooperate in order to ensure proper coordination between the proceedings as to the substance and the provisional relief. The court seized with the application for provisional measures shall seek information from the court of the main proceeding on the relevant circumstances of the case, particularly on the urgency of the measure and on any refusal of a similar measure by the court seized as to the substance. This suggests a kind of informal communication that cannot be performed by standard forms. Courts will be given broad discretion on how to obtain the information. With respect to the fact that a decision on provisional matters normally has to be issued within a very short period of time, communication must be direct and quick. The Commission' s proposal seems to assume that judges communicate personally by phone, skype or e-mail, a rather optimistic approach that requires judges to have good language skills. If translation is required, interaction becomes difficult and much slower. Only a very few judges will - more or less by chance - share a common language with their colleagues of the other Member State. Even if they speak English quite well it might not suffice to discuss complicated factual and legal issues. Language skills are still not a decisive criterion in the appointment of judges in most Member States. Law graduates who have studied abroad and have good foreign language skills tend rather to apply for well-paid positions in big law firms than to work as judges - this, at least, is the German experience.

Consequently, today it seems an illusion that regulations like the proposed Article 31 can in practice prove to be of value in many cases. Nobody can deny that cooperation and direct communication between courts will be the best way of handling some problems arising in cross-border proceedings but one should remain realistic. The need for close cooperation in international cases has been emphasised in the European Insolvency Regulation (EIR) already, ${ }^{81}$ albeit for different situations. Bowing to inevitable political compromise, the EIR to some extent allows parallel insolvency proceedings in different Member States. This situation can occur when the debtor has a branch or agency in a state other than the Member State where his or her centre of main interest is located and where courts have jurisdiction for main insolvency proceedings (Article 3[1] and [2] EIR). The EIR allows the opening of secondary insolvency proceedings in the Member State where the debtor has a branch or agency and thus protects local creditors with small claims. It might be asking too much of them to enforce their claims in the main proceedings conducted in a foreign language abroad. ${ }^{82}$ Parallel proceedings, however, require that the various liquidators or administrators of the proceedings

Regulation 134/2000, 29 May 2000, OJ L 160, at 1; cf. Recital 20.

82 G. Mäsch, in Rauscher, above n. 79, Art. 3 EG-InsVO no. 23 with further references. Art. 42 (2) EIR 
closely cooperate, particularly to coordinate proceedings with respect to a successful restructuring of the insolvent company or an effective realization of the total assets. Article 31 EIR, therefore, imposes an obligation on the insolvency representatives to provide information and to cooperate. ${ }^{83}$ The UNCITRAL Model Law on CrossBorder Insolvency (Article 25[1]) goes one step further and also asks insolvency courts in different states to cooperate. ${ }^{84}$ What makes sense in theory hits many obstacles in practice. ${ }^{85}$ It has to be admitted that for insolvencies that involve proceedings in several states, the language problem involved in the coordination of the proceedings might be the least troublesome as liquidation or reorganization of the debtor will be difficult in any case. Nevertheless, one can see that cooperation works better if both or all insolvency administrators can communicate in the same language ${ }^{86}$ For large international cases, it is recommended to establish, for example, special Internet chat rooms and common data pools and to use so-called protocols - formal agreements or at least guidelines for the cooperation agreed upon by the insolvency administrators - that have proved to be of value in the USA (with a common language in all US states!) and in UNCITRAL cases.$^{87}$ In 2011, the European Parliament adopted a resolution on recommendations to the Commission on 'insolvency proceedings in the context of EU company law' ${ }^{88}$ One recommendation on the insolvency of groups of companies emphasises the need for agreements on 'methods of communication, including language, frequency and means'. Liquidators in large proceedings are not under the same time pressure as courts that have to decide on provisional matters in the above-described situation and they can, of course, afford the cost of interpreters. ${ }^{89}$ In smaller cases this might be simply too expensive. It is often underlined that no matter whether the cooperation of courts or liquidators is concerned, personal and rather informal communication on the phone or face to face (without interpreters) is the best way to solve problems.$^{90}$ Needless to say, there can be no guarantee that this is possible and many cross-border cases will have to manage with a second-best solution.

\section{Conclusion}

Cross-border civil litigation and cooperation of courts in an area with 23 official languages inevitably cause practical problems. A number of European regulations tackle the language problem and have recourse to the use of standard forms available in all languages. ${ }^{91}$ Nevertheless, the EU Commission's proposals for cross-border civil proceedings and the effective enforcement of court decisions are very often based on the

allows foreign creditors at least to lodge their claims in the official language of the Member State of their domicile, habitual residence or registered office.

83 Cf. B. Hess, Europäisches Zivilprozessrecht, 2010, § 9 no. 60-62; H. Vallender, 'Gerichtliche Kommunikation und Kooperation bei grenzüberschreitenden Insolvenzverfahren im Anwendungsbereich der EuInsVO - eine neue Herausforderung für Insolvenzgerichte', Zeitschrift für Insolvenzrecht 59 (2008). It has been suggested that the obligation should be extended to insolvency courts: cf. O. Rossbach, Europäische Insolvenzverwalter in Deutschland (2006), at 243 with further references.

84 There is some dispute over whether this can be interpreted to impose an obligation on the courts or not: cf. Rossbach, above n. 83, at 243.

85 Cf. U. Ehricke, 'Die Zusammenarbeit der Insolvenzverwalter bei grenzüberschreitenden Verfahren nach der EuInsVO', Wertpapiermitteilungen 397 (2005).

86 G. L. Schmüser, Das Zusammenspiel zwischen Haupt- und Sekundärinsolvenzverfahren nach der EuInsVO (2009), 99 et seq.

87 Ehricke, above n. 85, at 402; Rossbach, above n. 83, at 245.

88 European Parliament, 15 November 2011, 2011/2006(INI).

89 P. Gottwald, Insolvenzrechtshandbuch (2010), § 133 no. 101-102 suggests that the costs of translation should be preferential claims against the assets of the receiving insolvency estate.

90 P. Mankowsi, 'Comment on the decision of the London High Court 11. 2. 2009 - (2009) EWHC 206 (Ch)', Neue Zeitschrift für Insolvenzrecht 450 (2009); A. Konecny, 'Europäische Insolvenzkultur(en) Kampf oder Harmonisierung', Neue Zeitschrift für Insolvenzrecht 416 (2008).

91 Recently, the Proposal for a Regulation on Online Dispute Resolution for Consumer Disputes (ODR) (COM [2011] 794 final) suggests the implementation of an interactive website for ODR. It should allow consumers and traders to submit complaints by using an electronic complaint form available in all official languages. 
idea that the judicial systems in all Member States are equal and that it therefore makes no difference where proceedings take place. This appears to be a rather unrealistic assumption as it definitely makes a difference for a party or applicant if proceedings are conducted in a foreign language. The observance of basic procedural rights (due process, right to be heard) depends to a large extent on the question whether court documents and pleadings are translated into the defendant's language and on the use of interpreters during court hearings. This is a particular problem for private individuals, consumers or SMEs. One has to accept that the use of translations and interpreters is inevitable in many situations although it carries the risk of mistake and misapprehension. All key actors involved must therefore be sensitive with respect to possible inadequacy and misunderstandings.

In any case, European legislatures and authorities have to realise that the growing together of Member States and the pushing back of national sovereignty in many respects does not justify the cutback in the fundamental rights of individuals for the sake of faster and more efficient proceedings. The approach taken by Article 8 ESR and the shifting of the 'language risk' with respect to documents instituting proceedings against the defendant is a misguided development. For documents initiating court proceedings we should strictly adhere to the requirement of translation provided by the plaintiff as the PTCP do in Principle 5.2. For court hearings, trials and the taking of evidence we will probably see different handling in terms of language in the future: In cross-border commercial litigation involving global actors as parties there will be a tendency to use English as a working language if judges gradually catch up with the language skills already available in big law firms and legal departments. ${ }^{92}$ For the rest, one might hope that the use of translation services will become self-evident and that translations will be of good quality and available at reasonable cost.

The cooperation of courts in Europe is a fascinating concept, but it is still in its early stages. Court-to-court communication via standard forms available in all 23 official languages is not a perfect solution but offers a good start. For more complex situations such as the coordination of provisional measures or parallel insolvency proceedings we need to develop manuals and guidebooks like the ALI Guidelines to Court-to-Court Communication in Cross-Border Cases,${ }^{93}$ which is translated into different languages. With an increasing number of cross-border cases, Member States will realise the growing importance of language skills within the judiciary. The triumph of English as an unofficial working language is probably inescapable for communication between courts and is sometimes the only way to make informal communication possible. With respect to regular hearings and formal depositions, I would like to sound a warning about a certain pressure that might build up on courts, judges, lawyers and other key actors to communicate in (bad) English instead of calling in (expensive) interpreters. Reliable interaction is of the utmost importance with respect to legal proceedings. Therefore, nobody should be afraid of suggesting the consultation of an interpreter no matter how expensive and time-consuming it may be.

\footnotetext{
92 It remains to be seen whether this will be a real success story. Important objections refer not only to the risk of misunderstanding and lack of accuracy but suspect a violation of the constitutional guarantee that trials and court hearings are open to the public (which implies that the public must be able to follow the hearing): cf. W. Ewer, 'Das Öffentlichkeitsprinzip - Ein Hindernis für die Zulassung von Englisch als konsensual-optionaler Gerichtssprache', Neue Juristische Wochenschrift 1323 (2010) (rejecting this argument).

${ }_{93}$ The Guidelines were drafted for international insolvency proceedings and are presently available in 15 different languages: cf. <www.justiz.nrw.de/WebPortal_en/projects/ieei/documents/public_papers/ guidelines/index.php>.
} 
